\author{
Asian Journal of \\ Medical and Biological Research \\ ISSN 2411-4472 (Print) 2412-5571 (Online) \\ www.ebupress.com/journal/ajmbr
}

\title{
Article \\ Epidemic behavior of the etiological agent of infectious coryza in layer chicken of Bangladesh with isolation, identification and pathogenicity study
}

\author{
Mir Rowshan Akter ${ }^{1}$, Md. Shahidur Rahman Khan ${ }^{2}$, Md. Mostafizer Rahman ${ }^{1}$, S. M. Lutful Kabir ${ }^{2}$ and Md. Abu \\ Sayed Khan ${ }^{3}$ \\ ${ }^{1}$ Department of Microbiology, Hajee Mohammad Danesh Science and Technology University, Dinajpur-5200, \\ Bangladesh \\ ${ }^{2}$ Department of Microbiology and Hygiene, Bangladesh Agricultural University, Mymensingh, Bangladesh \\ ${ }^{3}$ Bridge Pharmaceuticals Ltd., House \# 231, Lane \# 16, Mohakhali DOSH, Dhaka, Bangladesh
}

*Corresponding author: Dr. Mir Rowshan Akter, Department of Microbiology, Hajee Mohammad Danesh Science and Technology University, Dinajpur-5200, Bangladesh. E-mail: akter.rowshan@ gmail.com

Received: 07 March 2016/Accepted: 21 March 2016/Published: 31 March 2016

\begin{abstract}
The present study was selected as infectious coryza is one of the major problems affecting poultry industry in the developing country like Bangladesh and the reports regarding infectious coryza are yet not be documented considering epidemiological investigation, proper isolation, identification and pathogenicity study. The epidemic behavior of the etiological agent of this disease were studied based on age, sex, breed, spatial and temporal differences after collection of samples suspected to be infected with infectious coryza in layer chicken of Bangladesh. The incidence rate of infectious coryza from field cases were recorded as per information received from farmers by using a structured questionnaire and also clinical signs and symptoms. The disease was very high in laying hen $(18.38 \%)$ in Sylhet and growing birds $(7.25 \%)$ in Khulna in comparing with prelaying stage $(2.07 \%)$ also in Sylhet region of Bangladesh. In this study no significant differences was observed as their location variation except Sylhet (9.2\%) in comparison with other areas (Rangpur - 8.76\%, Rajshahi $-8.82 \%$, Khulna $-8.83 \%$, Dhaka -8.72 and Chittagong - 8.65\% respectively) of Bangladesh but significant differences was observed as their age group. However, the incidence rate of this disease was found to be very high during winter $(8.77 \%)$ in compare with summer $(0.42 \%)$ season. Moreover, during investigation a total of 122 samples were collected from different areas of Bangladesh for the period of March 2011 to February 2014. The higher rate of incidence of A. paragallinarum was found in Sylhet (66.66\%) and lowest in Dhaka (43.75\%). The association of A. paragallinarum with different seasons revealed that higher incidence rate was found in winter season (52.26\%) in comparison with summer season (1.85\%). The suspected positive isolates were subjected to experimental pathogenicity study in natural host for there - isolation of A. paragallinarum was done as per Kotch postulates.
\end{abstract}

Keywords: epidemiology; incidence; pathogenicity; infectious coryza; layer chicken

\section{Introduction}

Infectious Coryza (IC) is an infectious and contagious respiratory disease of chickens. The disease is characterized by nasal discharge, facial swelling, sneezing, coughing, labored breathing, anorexia and fetid odor of the exudates. The causative agent is Avibacterium (A.) paragallinarum a Gram negative non-motile, rod shaped organism. The incubation period is 1 to 3 days with duration of the disease 14 days in the infected individual bird. Transmission occurs by direct bird to bird contact, inhalation of infectious aerosols, coughed into the air, or through ingestion of contaminated feed and water. The organism can be transferred on contaminated clothing, equipment and fomites. The greatest economic losses result from poor growth performance in growing birds and marked reduction $(10-40 \%)$ in egg production in laying hens (Zhang et al. 2003). Early treatment of IC may be of value; however, the infected chickens continue to be carrier of the 
bacterium. One of the reasons for the success of survival for this bacterium is that after recovering from infection, birds become carriers of the bacterium, therefore aiding the spread of A. paragallinarum (De Blieck, 1948). In Bangladesh, the information on IC is very scanty except Talha et al. 2001, Akter, 2012 and Ali et al. 2013.These investigators focused on preliminary isolation, identification and pathogenicity study for IC. For the effective control of a specific disease of a specific host in a country must rely on the geographical and epidemiological information based on age, sex, breed, spatial and temporal differences. As per literature review in the context of Bangladesh no information as per mention earlier was recorded. Moreover, the prevention and control of IC depends on strict biosecurity, use of antiseptics, disinfectants, antibiotics and finally specific vaccines to IC. But the problem is that due to serotype or serovar or strain variation of A. paragallinarum, this fastidious disease control by using vaccine is sometimes difficult. From the above cited information and hypothesis in the context of Bangladesh the etiological agent identification based on age, sex, breed, spatial and temporal differences with confirmatory diagnosis of a specific serotype or serovar or strain of $A$. paragallinarum is a must before developing and producing a specific vaccine to control this fastidious disease. Considering the idea the research work was selected as IC is one of the major problems affecting poultry industry in the developing country like Bangladesh and the reports regarding IC are yet not be documented considering epidemiological investigation, proper isolation, identification, characterization and control of this remedy although this problem has become a constant threat to our poultry industry. By justifying the research in the context of Bangladesh and neighboring countries of the world, the present study was conducted for the epidemiological investigation, proper isolation, identification and characterization of field isolate of $A$. paragallinarum by using morphological, cultural, biochemical and pathgenicity study considering as entirely a new work in Bangladesh.

\section{Materials and Methods}

\subsection{Selection of study area}

This study was conducted at different areas (Rangpur, Rajshahi, Sylhet, Dhaka, Chittagong and Khulna) of Bangladesh during the period from March, 2011 to February 2014. The epidemic behavior of the etiological agent of infectious coryza (IC) were studied based on age, sex, breed, spatial and temporal differences. The samples were collected aseptically from the suspected layer flocks and brought to the Department of Microbiology (Bacteriology laboratory and Molecular Biology laboratory), Hajee Mohammad Danesh Science and Technology University (HSTU), Dinajpur.

\subsection{Collection of data and samples}

The epidemic behavior of etiological agent of IC from field cases were recorded (Table 1) as per information received from farmers by using a structured questionnaire and also clinical signs and symptoms. The date of collection, age, sex, breed, clinical signs and symptoms and environmental history were recorded for each case. A total of 122 (Table 2) samples; Nasal and tracheal exudates (Figure 1), visceral organs like liver, lung, heart were collected from birds suspected to be infected with IC during epidemiological investigation at different areas (Rangpur, Rajshahi, Sylhet, Dhaka, Chittagong and Khulna) of Bangladesh for the proper isolation and identification of bacterial pathogen by using morphological, cultural, biochemical test and pathogenicity study. Precautions were taken to avoid contamination of one sample with other.

\subsection{Experimental birds}

The birds were divided into three groups as group - A (0-9 weeks old), group - B (10-20 weeks old) and group C (above 20 weeks old) respectively. A total of 36 farms (2 farms for each age group) were studied for epidemiological investigation of IC in layer chicken of Bangladesh.

\subsection{Study of epidemic behavior of the etiological agent of infectious coryza in layer chicken}

\subsubsection{Visit the selected layer farms}

Visit the selected layer farms at different areas of Bangladesh (Rangpur, Rajshahi, Sylhet, Dhaka, Chittagong and Khulna) and the surveillance of epidemic behavior of the etiological agent of infectious coryza (IC) were studied based on age, sex, breed, spatial and temporal differences.

\subsubsection{Collection of information and data}

The information and data about the outbreak of IC were recorded as per structured questionnaire mentioned in this study for the surveillance of the etiological agent of IC in layer chicken. The collected data were summarized for the occurrence or absence of IC in that specific farm. 


\subsubsection{Feeding and housing}

Commercial balanced diet and clean drinking water was supplied ad libitum in deep litter system.

\subsubsection{Health status}

Information about the sources of egg or chicks and biosecurity measures including structural, conceptual and operational were recorded in structured questionnaire.

\subsubsection{History of disease}

Regular deworming maintained by using anthelmantic at 2 (two) month's interval in the selected farm was recorded. The history, clinical signs and symptoms of any respiratory diseases were also observed and recorded from the suspected to be infected bird.

\subsubsection{Vaccination and medication}

All layer chickens were vaccinated against Newcastle disease, Fowl pox and Infectious Bursal disease according to the manufacturer recommendation and infected birds were treated by using sulphar drugs and broad spectrum antibiotics.

\subsection{Isolation and identification of causal agent of IC}

\subsubsection{Cultural characterization}

Isolation of bacterial pathogen from suspected samples were carried out by culturing the samples on blood agar and chocolate agar plate cross streaked with Staphylococcus spp. The inoculated plates are then incubated at $37^{\circ} \mathrm{C}$ with $5-10 \% \mathrm{CO}_{2}$ for $24-48$ hours. Identification of the bacterial agent from the pure culture were carried out based on their colony characteristics, satellitism phenomenon and hemolysis pattern as described by Blackall, et al., 1997 and Chen et al., 1998.

\subsubsection{Morphological characterization}

The colonies from pure culture were then studied for its morphological characters by Gram's stain described by Buxton and Fraser, 1977.

\subsubsection{Biochemical characterization}

Different biochemical tests were employed to the organism like different Sugar's fermentation, Indol production, Voges-Proskauer, Methyl red, Hydrogen sulphide production and Nitrate reduction tests, Catalase, Dulcitol and Motility test to confirm the pathogen as Avibacterium paragallinarum.

\subsection{Experimental pathogenicity tests}

\subsubsection{Organism}

The local strain of $A$. paragallinarum was isolated from IC outbreaks in laying flocks then it was used for the experimental pathogenicity test in natural host for the determination of type of organisms.

\subsubsection{Inoculum preparations}

One single colony of $A$. paragallinarum was picked up from blood agar and placed in nutrient broth and cultured for 48 hours. Inoculation dose of $A$. paragallinarum $(1 \mathrm{ml} /$ bird) was prepared according to the procedure described by Islam 2010 for inoculation on 14 day's old chicks.

\subsubsection{Experimental designs}

A total of 30 day old layer chicks were collected and equally divided into two groups (A and $B, N=15$ ). On day 14 of age, the chicks of group A were inoculated through the intranasal route with $1 \mathrm{ml}$ of 2 days old culture broth of A. paragallinarum whereas the chicks of group B were kept as uninoculated control group. Clinical signs observation, postmortem study and re-isolation of A. paragallinarum were performed at interval of day 3 , 5 and 7 of post inoculation.

\subsubsection{Gross lesion studies}

All the internal organs including nasal passage were examined and gross lesions were recorded (nasal discharge, sneezing, conjunctivitis, swelling of sinuses and facial oedema) as Yamamoto, 1980. The inflammatory lesions of different organs (congestion, hemorrhage, swelling, mucus, etc.) were graded as $\pm=$ almost absence of lesion, $+=$ mild lesion,$++=$ moderate lesion and $+++=$ severe lesion. 


\subsubsection{Re-isolation of Avibacterium paragallinarum}

After the development of clinical signs of infectious coryza, the birds were scarified humanely and necropsied for observation of post-mortem lesions at day 7 of post inoculation. Muciod exudates from nasal cavities and infraorbital sinus were collected with sterile loop and streaked directly on to blood agar media plates containing NAD with $5-10 \% \mathrm{CO}_{2}$ for re-isolation of the bacteria from the experimentally infected birds according to the procedures followed by Kridda et al., 2012.

\subsection{Maintenance of stock culture}

During the experiment it was necessary to preserve the isolated organisms for longer periods. For this purpose, pure culture of the isolated organisms was stored in $20 \%$ sterilized glycerin and sealed with paraffin wax and stored at $-80^{\circ} \mathrm{C}$ in freezer for future use.

\section{Results and Discussion}

The epidemic behavior of the etiological agent of infectious coryza (IC) was studied for the first time in layer chicken of Bangladesh as per structured questionnaire. During investigation the birds were observed for clinical signs and symptoms and 122 samples were collected from birds suspected to be infected with IC based on age, sex, breed, spatial and temporal differences for proper isolation, identification and pathogenicity study of the etiological agent of the disease. The results are presented below:

\subsection{Results of epidemiological investigations}

3.1.1. Study on epidemic behavior of the etiological agent of infectious coryza (IC) in layer chicken of Bangladesh

\subsubsection{Study on incidence of IC based on age, sex, breed and spatial differences}

The epidemic behavior of the etiological agent of IC was studied at different areas of Bangladesh based on age, sex, breed, spatial and temporal differences. In this study period a total of 26900 (Table 4) layer chickens were observed on 36 farms for two times considering winter and summer season when the disease is prevailing. The rate of incidence of IC was recorded very high in laying hen (18.38\%) in Sylhet and growing birds (7.25\%) in Khulna in comparing with prelaying stage (2.07\%) also in Sylhet region of Bangladesh (BD) are presented in Table 4. As per location variation the incidence of IC was also recorded slightly high (9.2\%) in Sylhet comparing with other areas of Bangladesh are presented in Table 3. The highest incidence in Sylhet might be due to marshy environmental factor of this area. This findings supported by the Byarugaba et al. 2007.

\subsubsection{Study on incidence of $I C$ in stipulations of temporal or seasonal variation}

In this investigation 26900 birds were observed in 36 farms for each season (winter and summer) at various areas of BD for recording the rate of incidence of IC in layer chicken. The incidence rate was found to be very high in winter $(8.77 \%)$ in compare with summer $(0.42 \%)$ season are presented in Table 4 . Our present findings supported by Terzolo et al., 1993, Chen et al., 1993 and Blackall et al. 1997.

\subsubsection{Study on incidence rate of Avibacterium paragallinarum after collection of samples from suspected} layer chickens during epidemic investigation

3.1.2.1. Determination of incidence rate of $A$. paragallinarum in suspected birds based on age, sex and breed

A total of 122 samples were screened by epidemiological investigation of which the overall incidence rate of Avibacterium paragallinarum was detected as $47.54 \%$ (Table 5). The incidence rate was varied in terms of age (Table 5). In this study it was observed that incidence of Avibacterium paragallinarum was very high in laying hen $(52.8 \%)$ and growing birds (42.8) in compare with the prelaying stage (16.6\%) are presented in Table 5. This findings supported by the earlier observation of Blackall et al. 1997. This increased incidence rate of A. paragallinarum in layer chicken might be due to increased length of exposure to pathogens compared to grower and prelaying stage. 
Asian J. Med. Biol. Res. 2016, 2 (1)

Table 1. Study of epidemic behavior of etiological agent of IC at different areas of Bangladesh as per structured questionnaire and clinical sings and symptom.

\begin{tabular}{|c|c|c|c|c|c|c|c|c|c|}
\hline \multirow{2}{*}{$\begin{array}{l}\text { Spatial/ } \\
\text { Location/ } \\
\text { Area of farm }\end{array}$} & \multirow{2}{*}{$\begin{array}{l}\text { No. of } \\
\text { farm } \\
\text { observed }\end{array}$} & \multicolumn{3}{|c|}{$\begin{array}{l}\text { Total No. of birds observed in a flock } \\
\text { as per age (wks) group }\end{array}$} & \multirow[t]{2}{*}{ Sex } & \multicolumn{2}{|c|}{ Breed } & \multicolumn{2}{|l|}{ Season } \\
\hline & & $0-9$ & $10-20$ & $>20$ & & IB & HB & Winter & Summer \\
\hline \multirow[t]{6}{*}{ Rangpur } & 1 & 850 & - & & Female & + & & & \\
\hline & 2 & 550 & & & & & & & \\
\hline & 3 & & 720 & & & & & & \\
\hline & 4 & & 680 & & & & & & \\
\hline & 5 & & & 820 & & & & & \\
\hline & 6 & & & 700 & & & & & \\
\hline \multirow{6}{*}{ Rajshahi } & 1 & 600 & & & & & + & & \\
\hline & 2 & 750 & & & & & & & \\
\hline & 3 & & 900 & & & & & & \\
\hline & 4 & & 700 & & & & & & \\
\hline & 5 & & & 850 & & & & & \\
\hline & 6 & & & 900 & & & & & \\
\hline \multirow[t]{6}{*}{ Khulna } & 1 & 650 & & & & & + & & \\
\hline & 2 & 550 & & & & & & & \\
\hline & 3 & & 680 & & & & & 26900 & 26900 \\
\hline & 4 & & 500 & & & & & & \\
\hline & 5 & & & 850 & & & & & \\
\hline & 6 & & & 650 & & & & & \\
\hline \multirow[t]{6}{*}{ Dhaka } & 1 & 500 & & & & + & & & \\
\hline & 2 & 950 & & & & & & & \\
\hline & 3 & & 750 & & & & & & \\
\hline & 4 & & 850 & & & & & & \\
\hline & 5 & & & 860 & & & & & \\
\hline & 6 & & & 1050 & & & & & \\
\hline \multirow{6}{*}{ Chittagong } & 1 & 500 & & & & + & & & \\
\hline & 2 & 1200 & & & & & & & \\
\hline & 3 & & 780 & & & & & & \\
\hline & 4 & & 640 & & & & & & \\
\hline & 5 & & & 800 & & & & & \\
\hline & 6 & & & 900 & & & & & \\
\hline \multirow[t]{6}{*}{ Sylhet } & 1 & 800 & & & & & + & & \\
\hline & 2 & 500 & & & & & & & \\
\hline & 3 & & 825 & & & & & & \\
\hline & 4 & & 675 & & & & & & \\
\hline & 5 & & & 600 & & & & & \\
\hline & 6 & & & 820 & & & & & \\
\hline Total & 36 & 8400 & 8700 & 9800 & & & & 53800 & \\
\hline
\end{tabular}

IC = Infectious Coryza 
Table 2. Samples collected from suspected birds based on age, sex, breed, spatial and temporal differences during epidemic investigation.

\begin{tabular}{|c|c|c|c|c|c|c|c|c|c|c|c|c|}
\hline \multicolumn{3}{|c|}{ Age (wks) } & \multirow[t]{2}{*}{ Sex } & \multicolumn{2}{|c|}{ Breed } & \multirow[t]{2}{*}{$\begin{array}{l}\text { Spatial/ } \\
\text { Area }\end{array}$} & \multicolumn{2}{|l|}{ Season } & \multicolumn{3}{|c|}{$\begin{array}{l}\text { Name } \\
\text { of collected } \\
\text { samples }\end{array}$} & \multirow[t]{2}{*}{$\begin{array}{l}\text { Total } \\
\text { number of } \\
\text { samples } \\
\text { tested }\end{array}$} \\
\hline $0-9$ & $10-20$ & $>20$ & & IB & HB & & Summer & Winter & NS & TS & VO & \\
\hline 7 & 5 & 30 & & + & & Rangpur & 9 & 33 & 18 & 8 & 16 & 42 \\
\hline 5 & 2 & 10 & & & + & Rajshahi & 2 & 15 & 4 & 1 & 12 & 17 \\
\hline 3 & 1 & 10 & & & + & Sylhet & 6 & 8 & 10 & 4 & 0 & 14 \\
\hline 2 & 2 & 12 & Female & + & & Dhaka & 0 & 16 & 5 & 7 & 4 & 16 \\
\hline 1 & 0 & 08 & & + & & Chittagong & 0 & 9 & 9 & 0 & o & 9 \\
\hline 3 & 2 & 19 & & & + & Khulna & 2 & 22 & 15 & 0 & 9 & 24 \\
\hline 21 & 12 & 89 & & & & & & & & & & \\
\hline
\end{tabular}

*NS = Nasal S\swab, TS = Tracheal swab, VO = Visceral organ, IB = Isa Brown, HB = Hyline Brown

Table 3. Study on epidemic behavior of infectious coryza in layer chicken of Bangladesh based on age, sex, breed and spatial differences.

\begin{tabular}{|c|c|c|c|c|c|c|c|c|c|}
\hline \multirow[t]{2}{*}{$\begin{array}{l}\text { Location or } \\
\text { area of } \\
\text { farm }\end{array}$} & \multirow[t]{2}{*}{$\begin{array}{l}\text { No. of } \\
\text { farms } \\
\text { observed }\end{array}$} & \multicolumn{3}{|c|}{$\begin{array}{l}\text { Total No. of birds in a } \\
\text { flock with their age (wks) } \\
\text { group }\end{array}$} & \multirow{2}{*}{$\begin{array}{l}\text { No. of birds } \\
\text { infected in flock } \\
\text { with respiratory } \\
\text { disorder (IC) }\end{array}$} & \multicolumn{4}{|c|}{$\begin{array}{l}\text { Incidence rate (\%) of IC as their } \\
\text { age group (wks) and location }\end{array}$} \\
\hline & & $0-9$ & $10-20$ & $>20$ & & $0-9$ & $10-20$ & $>20$ & Location \\
\hline \multirow[t]{2}{*}{ Rangpur } & & 1400 & & & 99 & 7.07 & & & 8.76 \\
\hline & & & 1400 & 1520 & $\begin{array}{l}18 \\
274\end{array}$ & & 1.2 & 18.03 & \\
\hline \multirow[t]{2}{*}{ Rajshahi } & & 1350 & & $1 J \angle 0$ & 91 & 6.74 & & & 8.82 \\
\hline & 36 & & 1600 & & 13 & & 1.19 & & \\
\hline \multirow[t]{3}{*}{ Khulna } & & 1200 & & 1750 & $\begin{array}{l}314 \\
87\end{array}$ & 7.25 & & 17.94 & 8.83 \\
\hline & & & 1180 & & 17 & & 1.44 & & \\
\hline & & & & 1500 & 267 & & & 17.80 & \\
\hline \multirow[t]{3}{*}{ Dhaka } & & 1450 & & & 97 & 6.69 & & & 8.72 \\
\hline & & & 1600 & & 21 & & 1.31 & & \\
\hline & & & & 1910 & 347 & & & 18.17 & \\
\hline \multirow{3}{*}{ Chittagong } & & 1700 & & & 111 & 6.53 & & & 8.65 \\
\hline & & & 1420 & & 22 & & 1.55 & & \\
\hline & & & & 1700 & 304 & & & 17.88 & \\
\hline \multirow[t]{3}{*}{ Sylhet } & & 1300 & & & 93 & 7.15 & & & 9.2 \\
\hline & & & 1500 & & 31 & & 2.07 & & \\
\hline & & & & 1420 & 261 & & & 18.38 & \\
\hline Total & 36 & 8400 & 8700 & 9800 & 2473 & 6.90 & 1.46 & 18.03 & \\
\hline Level of sig. & & & & & & 0.375 & & & $0.138 \mathrm{NS}$ \\
\hline
\end{tabular}

IC $=$ Infectious coryza, wks $=$ Weeks, NS $=$ Not Significant

Table 4. Study on incidence of infectious coryza in suspected birds as per seasonal variation.

\begin{tabular}{|c|c|c|c|c|}
\hline Seasons & $\begin{array}{l}\text { No. of farm } \\
\text { observed }\end{array}$ & No. birds observed in flock & $\begin{array}{l}\text { No. of birds affected } \\
\text { in flock }\end{array}$ & Incidence rate (\%) \\
\hline Winter & 36 & 26900 & 2359 & 8.77 \\
\hline Summer & 36 & 26900 & 114 & 0.42 \\
\hline Total & 72 & 53800 & 2473 & \\
\hline Level of sig. & & & $0.447 \mathrm{NS}$ & \\
\hline
\end{tabular}

NS $=$ Not Significant 
Table 5. Determination of incidence rate of $A$. paragallinarum in suspected birds based on age, sex and breed.

\begin{tabular}{|c|c|c|c|c|c|c|c|c|c|c|c|c|}
\hline \multicolumn{3}{|c|}{$\begin{array}{l}\text { Total number of } \\
\text { samples tested as } \\
\text { per age (wks) } \\
\text { group }\end{array}$} & \multirow[t]{3}{*}{ Sex } & \multicolumn{2}{|c|}{ Breed } & \multirow[t]{2}{*}{$\begin{array}{l}\text { Spatial or } \\
\text { area }\end{array}$} & \multicolumn{2}{|l|}{ Season } & \multicolumn{3}{|c|}{$\begin{array}{l}\text { Total No. of Positive } \\
\text { isolates }\end{array}$} & \multirow[t]{2}{*}{$\begin{array}{l}\text { Overall } \\
\text { Incidence } \\
\text { rate } \\
(\%)\end{array}$} \\
\hline $0-9$ & $\begin{array}{l}10- \\
20\end{array}$ & $>20$ & & IB & HB & & Summer & Winter & $\begin{array}{l}0-9 \\
\text { wks }\end{array}$ & $\begin{array}{l}10-20 \\
\text { wks }\end{array}$ & $\begin{array}{l}>20 \\
\text { wks }\end{array}$ & \\
\hline 7 & 5 & 30 & & + & & Rangpur & 9 & 33 & $09_{\mathrm{b}}$ & $02_{\mathrm{c}}$ & $47_{a}$ & \\
\hline 5 & 2 & 10 & & & + & Rajshahi & 2 & 15 & $(42.8)$ & (16.6) & $(52.8)$ & \\
\hline 3 & 1 & 10 & Female & & + & Sylhet & 2 & 12 & & & & \\
\hline 2 & 2 & 12 & & + & & Dhaka & 0 & 16 & & & & \\
\hline 1 & 0 & 08 & & + & & Chittagong & 0 & 9 & & & & 47.54 \\
\hline 3 & 2 & 19 & & & + & Khulna & 1 & 23 & & & & \\
\hline 21 & 12 & 89 & & & + & & & 108 & (42.8) & (16.6) & (52.8) & \\
\hline \multicolumn{4}{|c|}{ Level of sig. } & & & & $0.002 * *$ & & $0.001 *$ & & & $0.263 \mathrm{NS}$ \\
\hline
\end{tabular}

$* *=$ Significant at $1 \%$ level of probability $(\mathrm{p}<0.01)$, NS $=$ Not Significant, IB $=$ Isa brown, HB $=$ Highline brown, wks $=$ Weeks

Table 6. Determination of incidence rate of $A$ paragallinarum in suspected birds based on spatial and temporal differences.

\begin{tabular}{|c|c|c|c|c|c|c|c|c|}
\hline \multirow{2}{*}{$\begin{array}{l}\text { Spatial or } \\
\text { area }\end{array}$} & \multicolumn{2}{|c|}{$\begin{array}{l}\text { Name } \\
\text { of collected } \\
\text { samples }\end{array}$} & \multicolumn{2}{|c|}{$\begin{array}{l}\text { Season and total } \\
\text { number of samples } \\
\text { tested }\end{array}$} & \multicolumn{2}{|c|}{$\begin{array}{l}\text { No of positive } \\
\text { isolates }(\%)\end{array}$} & \multicolumn{2}{|c|}{$\begin{array}{l}\text { Overall Incidence rate } \\
(\%)\end{array}$} \\
\hline & NS & VO & Summer & Winter & Summer & Winter & Summer & Winter \\
\hline Rangpur & 18 & 16 & 9 & 33 & 1 & 19 & (11.11) & $(57.57)$ \\
\hline Rajshahi & 4 & 12 & 2 & 15 & 0 & 8 & & (53.33) \\
\hline Sylhet & 10 & 0 & 2 & 12 & 0 & 8 & & (66.66) \\
\hline Dhaka & 5 & 4 & 0 & 16 & 0 & 7 & & (43.75) \\
\hline Chittagong & 9 & o & 0 & 9 & 0 & 4 & & (44.44) \\
\hline Khulna & 15 & 9 & 1 & 23 & 0 & 11 & & $(47.82)$ \\
\hline Total $=$ & & & 14 & 108 & 1 & 57 & & \\
\hline & & & 122 & & & & 1.85 & 52.26 \\
\hline Level of sig. & & & & & $0.112 \mathrm{NS}$ & & & $4 \mathrm{NS}$ \\
\hline
\end{tabular}

NS $=$ Not Significant

Table 7. Determination of ' $V$ 'factor for the growth of $A$. paragallinarum by Staphylococcus aureus.

\begin{tabular}{ll}
\hline Name of the media & Colony characteristics \\
\hline Blood Agar & Small ,dew drop like nonhemolytic colonies \\
Chocolate Agar & Luxuriant growth \\
Chocolate Agar Cross streaked with Staphylococcus aureus. & Satellitic growth \\
\hline
\end{tabular}


Table 8. Chracterization of field isolates of $A$. paragallinarum by staining or morphological and biochemical examination.

\begin{tabular}{|c|c|c|c|c|c|}
\hline \multirow{2}{*}{$\begin{array}{l}\text { No. of } \\
\text { tested } \\
\text { isolates }\end{array}$} & \multirow[t]{2}{*}{ Test performed } & \multirow[t]{2}{*}{ Observation } & \multicolumn{2}{|c|}{ Response } & \multirow[t]{2}{*}{ Indication } \\
\hline & & & $\begin{array}{l}\text { Positive } \\
\text { isolates }\end{array}$ & $\begin{array}{l}\% \text { of Positive } \\
\text { isolates }\end{array}$ & \\
\hline 122 & $\begin{array}{l}\text { Microscopic } \\
\text { examination by } \\
\text { Gram's staining } \\
\text { TSI agar slant } \\
\text { reaction } \\
\text { Motility test by } \\
\text { MIU medium } \\
\text { Indole test } \\
\text { MR test } \\
\text { VP test } \\
\mathrm{H}_{2} \mathrm{~S} \text { Production }\end{array}$ & $\begin{array}{l}\text { Gram negative, coccobacilli } \\
\text { or short rod shaped } \\
\text { Ferment Glucose, } \\
\text { Sucrose \& Lactose } \\
\text { Absence of turbidity } \\
\text { No pink color ring at the } \\
\text { adjacent } \\
\text { Absence of red color indicate } \\
\text { MR test negative } \\
\text { No color change indicate VP } \\
\text { test negative } \\
\text { Absence of black coloration } \\
\text { at TSI slant indicate } \mathrm{H}_{2} \mathrm{~S} \\
\text { Production negative }\end{array}$ & 58 & $100 \%$ & $\begin{array}{l}\text { A. paragallinarum } \\
\text { A. paragallinarum } \\
\text { A. paragallinarum } \\
\text { A. paragallinarum } \\
\text { A. paragallinarum } \\
\text { A. paragallinarum } \\
\text { A. paragallinarum }\end{array}$ \\
\hline
\end{tabular}

$\overline{\mathrm{MR}}=$ Methyl red; $\mathrm{VP}=$ Voges Proskauer; $\mathrm{MIU}=$ =Motility indole urease

Table 9. Biochemical reactions of the isolate.

\begin{tabular}{lll}
\hline Test & Result & Indication \\
\hline Glucose & + & \\
Sucrose & + & \\
Lactose & + & A. paragallinarum \\
Indole & - & \\
Vogas Proskauer test & - & \\
Methyl Red test & - & \\
$\mathrm{H}_{2}$ S Production & - & \\
Motility & - & \\
Catalase & - & - \\
Dulcitol & - & \\
\hline$+=$ Positive; = Negative; MR = Methyl red; VP = Voges Proskauer; MIU =Motility indole urease
\end{tabular}

Table 10. Experimental pathogenicity study.

\begin{tabular}{|c|c|c|c|c|}
\hline $\begin{array}{l}\text { Days Post } \\
\text { Inoculation }\end{array}$ & Signs & Postmortem lesions & $\begin{array}{l}\text { Group - A } \\
\text { (Inoculated with } \\
\text { A. paragallinarum) }\end{array}$ & $\begin{array}{l}\text { Group - B } \\
\text { (Control group) }\end{array}$ \\
\hline 3 & $\begin{array}{l}\text { Facial swelling, } \\
\text { Watery nasal } \\
\text { discharge, } \\
\text { conjunctivitis }\end{array}$ & $\begin{array}{l}\text { Grayish white } \\
\text { exudates in nasal } \\
\text { cavities, }\end{array}$ & 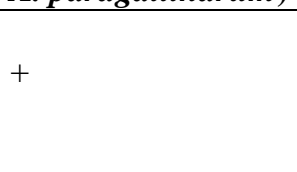 & - \\
\hline 5 & $\begin{array}{l}\text { Disappearance of } \\
\text { nasal discharge and } \\
\text { lacrimation, swelling } \\
\text { of face }\end{array}$ & $\begin{array}{l}\text { Yellowish catarrhal } \\
\text { exudates in larynx and } \\
\text { nasal cavities }\end{array}$ & + & - \\
\hline 7 & $\begin{array}{l}\text { Swelling of face, } \\
\text { depression and } \\
\text { inability to move }\end{array}$ & $\begin{array}{l}\text { Congestion of lung and } \\
\text { trachea, air sacs became } \\
\text { cloudy and thickened with } \\
\text { foamy exudates }\end{array}$ & + & - \\
\hline
\end{tabular}

$+=$ Positive, $-=$ Negative 


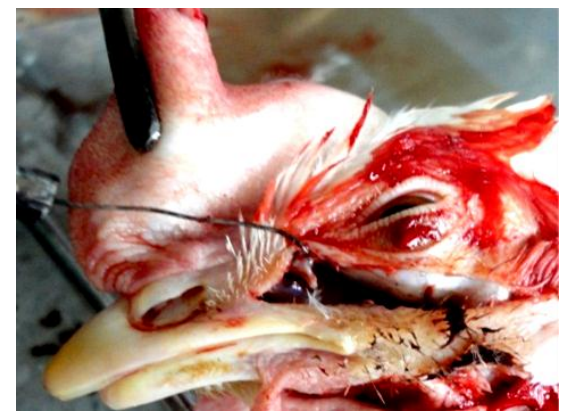

Figure 1. Collection of exudates from sinus cavity.

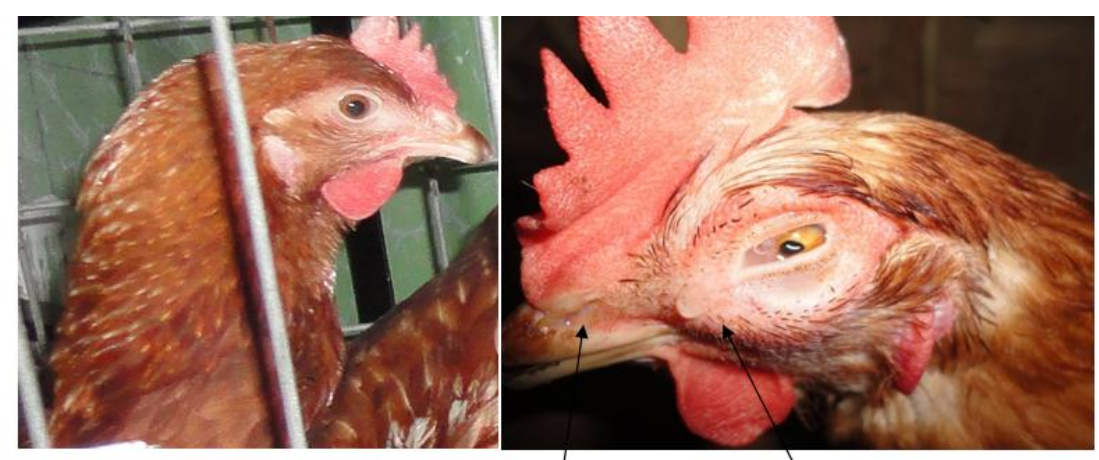

Figure 2. Facial swelling with nasal and ocular discharge (Right).
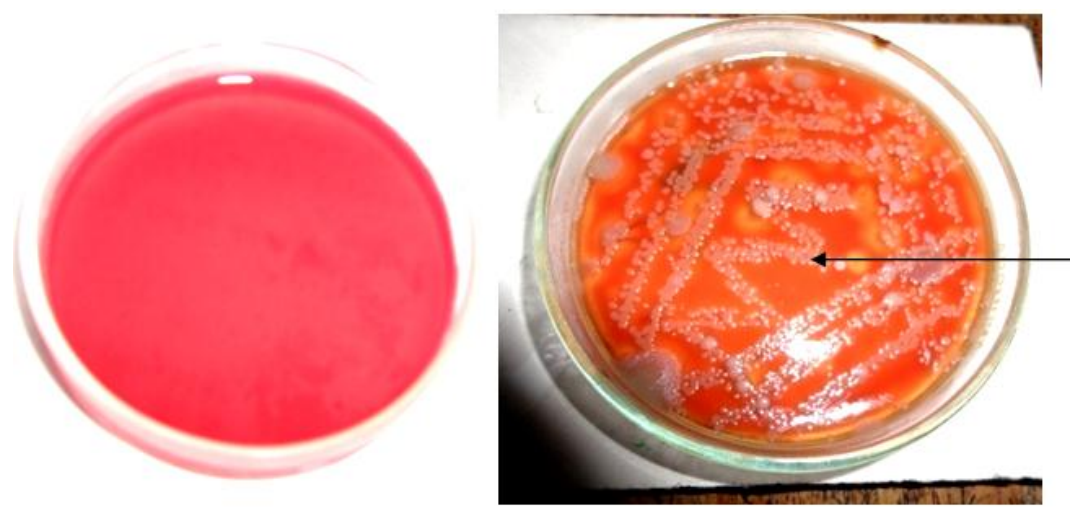

Figure 3. Growth of A. paragallinarum on Blood Agar (Right).

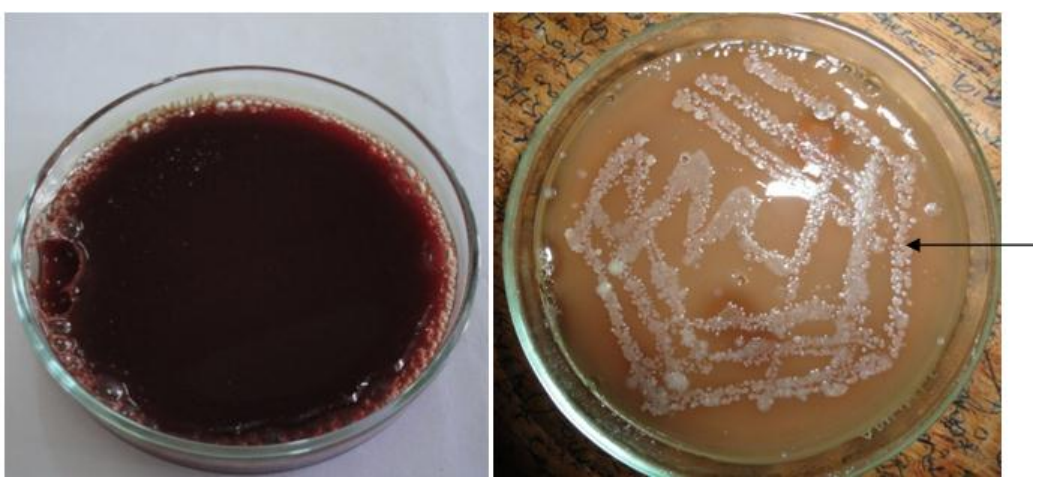

Figure 4. Growth of A. paragallinarum on Chocolate Agar (Right). 


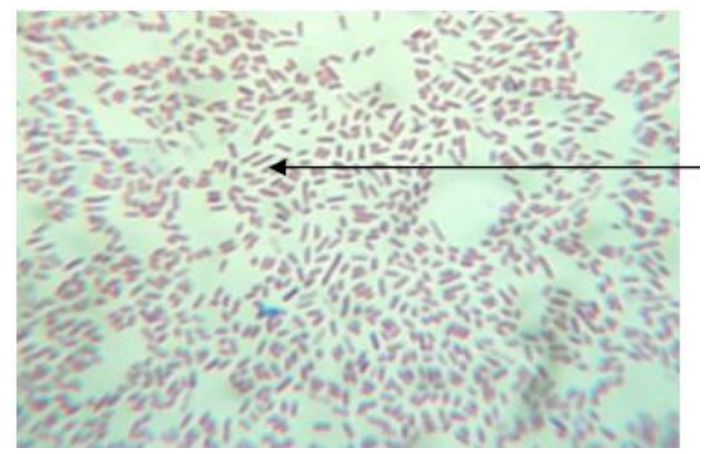

Figure 5. Gram's staining of $A$. paragallinarum.

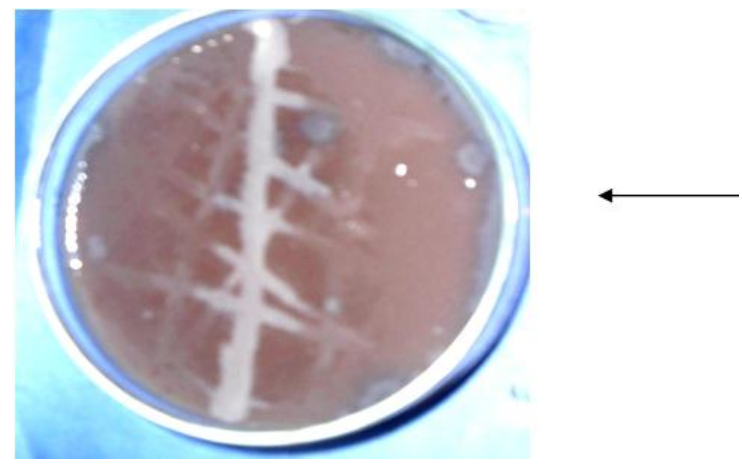

Figure 6. A. paragallinarum showing satellitism phenomenon around $\mathrm{V}$ factor.

\subsubsection{Determination of incidence rate of $A$. paragallinarum in suspected birds based on spatial and temporal differences}

The incidence of A. paragallinarum in Rangpur, Rajshahi, Sylhet, Dhaka, Chittagong and Khulna were found to be $57.57 \%, 53.33 \%, 66.66 \%, 43.75 \%, 44.44 \%$ and $47.82 \%$ respectively (Table 6). The highest incidence was found in Sylhet $(66.66 \%)$ and the lowest in Dhaka $(43.75 \%)$ in comparison with other areas of BD mentioned earlier. In this study, 58 samples were found to be positive for A. paragallinarum from 122 suspected samples collected during epidemiological investigation. The association of A. paragallinarum with different seasons (Table 6) revealed that higher incidence was found in winter season $(52.26 \%$ ) in comparison with summer season $(1.85 \%)$. This observed variation in incidence of $A$. paragallinarum at various areas and seasons of Bangladesh could be related with several factors such as geoclimatic situation, passive immunity level, infecting dose, simultaneous infection with other respiratory pathogens, stress, managemental practice, biosecurity failure and different locations of the study areas.

3.2. Results of isolation and characterization of $A$. paragallinarum by morphological, cultural and biochemical properties

\subsubsection{Isolation and characterization of $\boldsymbol{A}$. paragallinarum by cultural properties}

The birds in the infected flock had facial swelling, nasal and lacrimal discharge, open mouth breathing and mucoid discharge from the nares. The clinical signs (Figure 2) are common features of infectious coryza. This present findings supported by the Droual et al. 1990, Horner et al.1992 Mouahid et al. 1992, Calnek et al. 1991 and Sandovel et al. 1994.The bacterium was recovered only from nares on blood agar (Small, dew drop like nonhemolytic colonies, Figure 3 and Table 7) and chocolate agar (Luxuriant growth, Figure 4 and Table 7). No growth was recovered from samples like liver, lungs, heart streaked on different agars. The growth and morphological characteristics indicated that the isolated organism might be A. paragallinarum (Table 8), which was later confirmed by different biochemical tests (Table 9). This findings supported by the earlier observation of Terzolo et al. 1993, Rimler et al.1975 and Miflin et al.1999. The bacterium was isolated from nares on blood agar, chocolate agar and chocolate agar cross streaked with a nursery colony of Staphylococcus aureus as feeders. It was observed that satellitic growth patterns (Figure 6) of isolated bacterium might be A. paragallinarum, which was later confirmed by biochemical tests. 


\subsubsection{Characterization of $A$. paragallinarum by morphological and biochemical Properties}

The isolated organism was characterized by morphological characterization (Gram's staining technique, Figure 5, Table 8) and different biochemical (Table 9) tests. This observation revealed that the isolated organism was Gram negative, short rods or cocccobacilli arranged in single or pairs. It was also observed that caseopurulent air sac lesions in field cases of infectious coryza in layer chickens. This observation supported by Sameera 2001, Fujivara and Konno 1965, Blackall et al. 1989 and Rimler et al. 1975.

\subsection{Experimental pathogenicity test}

Among the infectious diseases of poultry, infectious coryza (IC) is an upper respiratory tract infection of chickens caused by a bacterial agent called A. paragallinarum, is one of the major problems affecting commercial poultry industry worldwide (Blackall et al. 1997). No systematic pathogenicity studies have been conducted by local isolates of $A$. paragallinarum in conjunction with epidemic behavior study of the etiological agent of this IC in Bangladesh. The present study describes experimental pathogenicity studies of field isolates of A. paragallinarum in susceptible layer chicks.

\subsubsection{Clinical signs}

The experimentally infected birds with the A. paragallinarum isolates were examined in detail at regular intervals of time up to 7days post inoculation for clinical signs and gross postmortem lesions. The clinical signs of infectious coryza in birds of Group A (inoculated with A. paragallinarum) appeared after $24 \mathrm{hrs}$ of infection characterized as oedematous swelling of face and infraorbital sinus and secretion of watery nasal discharge (Table 10). Some birds showed bilateral swelling of face and infraorbital sinuses, conjunctivitis, serous to mucoid nasal discharge with foul smelling, foamy lacrimation and induration of face after 3 DPI. After 5 days of infection, disappearance of nasal discharge and lacrimation but the birds still suffered from swelling of face after 7 DPI (Table10). This observation supported by other researchers; Kridda et al. 12010, Gayatri et al. 2010, Fujivara and Konno 1965, Blackall 1989 and Page 1962.The birds of group B (uninoculated control group) did not reveal any conspicuous clinical sign and lesion.

\subsubsection{Gross postmortem study}

A. paragallinarum infected birds of Group A (inoculated with A. paragallinarum) showed, infraorbital sinus cavities were filled with grayish white watery exudates at 3 DPI. Larger amount of yellowish cattarhal exudates with necrotic debris were found in upper larynx and nasal cavities after 5 DPI, while at 5 to 7 DPI trachea and lung revealed mild congestion. The air sacs became cloudy and thickened with foamy exudates after 5 to 7 DPI. On the other hand, the birds of group B (uninoculated control group) did not reveal any lesion related to the IC on day 3, 5 and 7 of post inoculation. This observation supported by other researchers; Fujivara and Konno 1965, Blackall 1989 and Page 1962.

\subsubsection{Re-isolation of $A$. paragallinarum at day 7 of post inoculation}

Re-isolation was performed only in tissues (nasal passage) showing postmortem lesions on day 7 of post inoculation (PI) according to the procedure described by Rimler et al. 1975.

\subsubsection{Gram's stain, biochemical tests, sugarfermentation test and catalase activity test}

Tentatively identified colonies of A. paragallinarum from nasal passage of day 7 of PI from blood agar media cross streaked with Staphylococcus aureus or extra supply of NAD were used for morphological study. The morphology of the isolated bacteria exhibited red (Gram's stain) color, small rod shaped Gram negative coccobacilli. A. paragallinarum isolate was able to ferment four basic sugars by producing acid (Table 8). These findings agreed with Sameera et al. 2001, Yamamoto1991, Sawata et al. 1982, Blackall 1989 and Haunshi et al. 2006.

\section{Conclusions}

Among economically important diseases of poultry, Infectious Coryza (IC) is an infectious and contagious respiratory bacterial disease in poultry industry causing heavy economic losses through morbidity and reduced (10 - 40\%) in egg production. In this study, the incidence was higher in laying hen (52.8\%) in compare with prelaying stage $(16.6 \%)$. In the present study a trend in increasing the incidence rate of infectious coryza was observed as their location (66.66) and seasonal (52.26\%) variations. This observed variation in incidence of infectious coryza in various areas of Bangladesh could be related with several factors such as geoclimatic situation, passive immunity level, infecting dose, simultaneous infection with other respiratory pathogens, 
stress, manage mental practice, biosecurity failure and different locations of the study areas. To prevent the spread of IC in laying hen, disease management strategies could be undertaken and introducing a continuous monitoring of organism by randomized detection of antibody by serological (HI) test, culling of infected and carrier bird and implementation of good husbandry practice with biosafety plan but it does not eliminate the carrier status of chickens. It is advisable to vaccinate the chickens with inactivated coryza vaccine to prevent economic losses. Considering this fact the research work will also extends for the production of vaccine candidate from the field isolate to control infectious coryza in layer chicken of Bangladesh.

\section{Acknowledgements}

We thank the Government of the People's Republic of Bangladesh for providing NSICT fellowship to Mir Rowshan Akter.

\section{Conflict of interest}

None to declare.

\section{References}

Akter S, 2012. Isolation and identification of Avibacterium paragallinarum from layer chickens. MS Thesis, Department of Pathology, Faculty of Veterinary Science, Bangladesh Agricultural University, Mymensingh2202.

Ali M, MS Hossain, S Akter, MAHNA Khan and MM Hossain, 2013. Pathogenesis of Infectious Coryza in Chickens (Gallus gallus) by Avibacterium paragallinarum Isolate of Bangladesh. The Agriculturists, 11: 3946.

Blackall PJ, M Matsumoto and R Yamamoto, 1997. Infectious coryza. In BW Calnek, HJ Barnes, CW Beard, LR McDougald, and YM Saif (eds.). Diseases of Poultry, 10th ed. Iowa State University Press: Ames, IA, pp. 179-190.

Blackall PJ, CJ Morrow, A McInnes, LE Eaves and DG Rogers, 1990. Epidemiologic studies on infectious coryza outbreaks in northern New South Wales, Australia, using serotyping, biotyping, and chromosomal DNA restriction endonuclease analysis. Avian dis., 34: 367 -376.

Blackall PJ, 1989.The Avian Haemophili. Clin. Microbiol. Rev., 2: 270-277. Byarugaba DK, UM Minga, PS Gwakisa, E Katunguka, M Bisgaard and JE Olsen, 2007. Virulence characterization of Avibacterium paragallinarum isolates from Uganda. Avian Pathol. , 36: 35-42.

Calnek BW, H John Barnes, CW Breed, WM Reid and HW Yodev, 1991. Diseases of Poultry, 9th Ed., Wolfe Publishing Ltd., USA. pp. 186-92.

Chen X, Zhang P, Blackall PJ and Feng W, 1993. Characterization of Haemophilus paragallinarum Isolates from China. Avian Dis., 37: 574-576.

Droual R, AA Bickford, BR Charlon, GL Cooper and SE Channing, 1990. Infectious coryza in meat chickens in the San Joaquin Valley of California. Avian Dis., 34: 1009-1016.

Fujiwara H and S Konno, 1965. Histopathological studies on infectious coryza of chickens. ii. Findings in experimentally infected cases. Natl. Inst. Anim. Health Q (Tokyo). 5: 86-96.

Gayatri Rr, R Ashish and MY Mahendra, 2010. Antimicrobial sensitivity pattern of Haemophilus paragallinarum isolated from suspected cases of infectious coryza in poultry. Vet. World, 3:177-181.

Haunshi S, B Dutta and SC Saxena, 2006. An outbreak of infectious coryza in Vanaraja poultry of Meghalaya. Ind. J. Vet. Pathol., 30: 55.

Horner RF, GC Bishop and C Haw, 1992. An upper respiratory disease of commercial chickens resembling infectious coryza, but caused by a V factor - idependent bacterium. Avian Pathol., 21: 421-427.

Kridda, Suwit and Niwat, 2010. An Outbreak of Avibacterium paragallinarum serovar B in a Thai Layer Farm. Th. J. Vet. Med., 40: 441- 444.

Miflin JK , X Chen, RR Bragg, JM Welgemoed, JM Greyling, RF Horner and PJ Blackall, 1999. Confirmation that PCR can be used to identify NAD-dependent and NAD- independent Haemophilus paragallinarum isolates. Onderstepoort J. Vet. Res., 66: 55- 57.

Mouahid M, KH Hhinz, Engelhard, R Mutters and W Mannheim, 1992. Characterization of Haemophilus paragallinarum by analysis of whole cell carbohydrates, fatty acids and phospholipids. Avian Pathol., 21: 127-136.

Page LA, 1962. Haemophilus infections in chickens. Characteristics of 12 Haemophilus isolates recovered from diseased chickens. Am. J. Vet. Res., 23:85-95. 
Rimler RB, EB Shotts and RB Davis, 1975. A growthmedium for the production of a bacterin for immunization against infectious coryza. Avian Dis.,19: 318-322.

Roberts DH, BS Hanson and L Timms, 1964. Observations in the incidence and significance of Haemophilus gallinarum in outbreaks of respiratory disease among poultry in Great Britain. Vet. Rec., 76:1512-1516.

Sameera A, RB Asif and M Khushi, 2001. Clinico-Therapeutic Observations on an Outbreak of Infectious Coryza. Int. J. Agri. Biol., 3: 531- 532.

Sandoval VE, HR Twerzolo and PJ Blackall, 1994.Complicated infectious coryza cases in Argentina. Avian Dis., 38: 672-678.

Sawata A, K Kume and Y Nakase, 1982. Hemagglutinin of Haemophilus paragallinarum serotype 2 organisms: Occurrence and immunologic properties of hemagglutinin. Am. J. Vet. Res., 43: 1311-1314.

Talha AFSM, MM Hossain, EH Chowdhury, ASM Bari, MR Islam and PM Das, 2001. Poultry diseases occurring in Mymensingh district of Bangladesh. Bangladesh Vet., 18: 20-23.

Terzolo HR, FA Paolicchi, VE Sandoval, PJ Blackall, T Yamaguchi and Y Iritani, 1993. Characterization of isolates of Haemophilus paragallinarum from Argentina. Avian Dis., 37: 310-314.

Yamamoto R, 1991. Infectious coryza: In: Diseases of Poultry, 9th ed. Hofstad MS, HJ Barnes, BW Calnek, WM Reid and JHW Yoder, Eds. Iowa University Press, Ames, Iowa, USA. pp.178-186.

Zhang PJ, M Miao, H Sun, Y Gong and PJ Blackall, 2003. Infectious Coryza due to Haemophilus paragallinarum serovar B in China. Aust. Vet. J. ,81:96-97. 